\title{
Analysis of the Differences and Linkage between Chinese and American Stock Markets
}

\author{
Huadong Liu \\ School of economics, Jinan University, Guangzhou, China \\ Email: reallhd@outlook.com
}

How to cite this paper: Liu, H.D. (2018) Analysis of the Differences and Linkage between Chinese and American Stock Markets. American Journal of Industrial and Business Management, 8, 700-709. https://doi.org/10.4236/ajibm.2018.83047

Received: January 31, 2018

Accepted: March 24, 2018

Published: March 27, 2018

Copyright (C) 2018 by author and Scientific Research Publishing Inc. This work is licensed under the Creative Commons Attribution International License (CC BY 4.0).

http://creativecommons.org/licenses/by/4.0/

(c) (i) Open Access

\begin{abstract}
This paper compares the stock markets of China and the United States from several aspects, such as the first class IPO market mechanism, secondary security market mechanism, and the market supervision mechanism. Overall, China's stock market lags behind the United States stock market. Then, this paper expounds the transmission channel of stock market linkage and the related theory of stock market linkage. Through the trade between countries, the economic spillover effect, the gradual increase of transnational listing, and the globalization of stock companies, the paper explores the related ways of Chinese and American stock markets from four aspects, and tries to analyze the formation mechanism of the linkage between China and America stock markets in four channels: International trade, financial capital, policy and expectation. Finally, a conclusion is drawn: With the development of China's economy and opening of the stock market system, the stock market linkage between China and the United States is increasing gradually.
\end{abstract}

\section{Keywords}

Stock Market, Diversity, Linkage, China, The United States

\section{Introduction}

With the process of economic globalization, China's capital market has gradually opened to the outside world, and the domestic and foreign economic ties have gradually increased. China's capital market has become an important part of the global capital market. With the increase of global economic integration and the increase of international capital flow, the phenomenon of rising and falling of international stock market is becoming more and more obvious. The phenomenon of stock market linkage has become a very important economic phenomenon in the international securities market. It is the result of domestic financial 
liberalization and financial internationalization.

The linkage between the stock market refers to the stock market between different countries which have a common trend, and there is a strong correlation between different market yields and price fluctuations, which makes the different stock market prices to achieve long-term stable trend. In recent years, the degree of economic integration has gradually deepened, and the form of international division of labor has also undergone major changes. With the rapid development of transnational corporations, the speed and scale of international capital flow are increasing rapidly, and the macroeconomic relations among countries in the world are becoming closer and closer, and the macroeconomic development shows a relatively significant correlation. As a "barometer" of macroeconomic, the international stock market has also appeared obvious linkage phenomenon in recent years, and has aroused widespread concern of scholars. Especially in the 1987, when the stock market crashed in the United States caused a global stock market decline, scholars began to pay attention to the mutual influence of the capital markets between countries [1].

Why do we study the stock market linkage? From the micro level, it helps securities investors to analyze portfolios, make securities pricing, analyze the securities market structure, judge stock market trends, and thus disperse risks and increase portfolio returns. At the same time, it also helps the listed companies to formulate financing strategies and realize the internationalization of capital. From a macro perspective, the study of the linkage between the stock market index at home and abroad reflects the degree of internationalization of China's securities market, and it is beneficial for the government to supervise the market and guard against financial risks.

\section{Comparative Analysis of Chinese and American Stock Markets}

\subsection{Comparison of Stock Market IPO System}

There are three differences in the IPO system between China and the United States: new share issuance system, the information disclosure system of new shares and the pricing mechanism of new shares.

China currently adopts the approval system, and the United States adopts the registration system. The approval system, the so-called substantive management principle, is represented by corporate law in all European countries. In accordance with the requirements of the examination and approval system for securities issuance, the issuance of securities shall not only be based on the full disclosure of the real conditions, but also be in conformity with the substantive conditions for the issuance of securities institutions. A qualified issuing company may obtain the issuance qualification and issue securities on the stock market after approval by the securities regulatory authority. The aim of the system is to prohibit the public issuance of securities of poor quality. Registration system means that when the issuer is preparing to issue securities, he must submit all the in- 
formation in accordance with the law in full, true and accurate to the securities authorities and apply for registration. As for the nature of the issuer's business, the issuer's financial resources, quality and development prospects, the issue of quantity and price and other substantive conditions are not as important elements of the issue of audit. If the competent authorities do not have any objections, the application shall automatically become effective after the submission of the declaration document. In the approval system, the government has carried out more administrative intervention, and even controlled the quantity and rhythm of IPO, which will increase the risk of moral hazard and rent-seeking undoubtedly, which Increased costs and reduced efficiency. The registration system emphasizes the game between the issuer and investors, where the government's role is only in real-time monitoring of information disclosure, and the price of the new issue of shares is entirely determined by the market. The differences of the new issue system between China and the United States have created great differences among listed companies. Most of the listed companies on the main board are state-owned enterprises, while the total amount of listed private enterprises accounted for $2 / 3$ of the total national output accounts for less. That is to say, the Chinese stock market is not able to reflect the actual development of China's economy. In the United States, the New York stock exchange and NASDAQ listed companies are mostly private enterprises, such as Apple, Google, Microsoft, GM and so on [2]. The value of the company in the stock market and its contribution to the U.S. economy roughly equal, that the U.S. stock market can play an economic barometer of the role.

Information disclosure system is also called public disclosure system. Chinese and American stock markets are similar in the arrangement of the issuer's information disclosure, but there are many differences in the actual implementation process. In China, there are obvious differences in the performance of listed companies before and after the listing. A considerable number of enterprises listed performance changes face, or even significant decline in performance. Thus, the quality of information disclosure of listed companies is relatively low, and there are still some defects in the government's supervision. In the United States stock market, the performance of listed companies is relatively stable, and basically consistent with the operation of listed companies. This shows that the quality of information disclosure of Listed Companies in the United States is higher, and the securities and Exchange Commission's supervision of the market is effective. Because of the strict supervision of the market by the securities and Exchange Commission, the information disclosed by the enterprise during the listing stage can be more accurate and truly reflect the operating conditions of the enterprise.

There are also significant differences between China and the United States in the IPO pricing mechanism. China's distribution methods include online purchase, offline distribution and placement to strategic investors. For institutional investors, the pricing method based on cumulative bid inquiry is adopted, and 
the fixed price pricing method is adopted for the general individual investors. And the United States stock market led by the agency, the commonly adopted IPO pricing method is the cumulative bidding pricing method. This pricing mechanism is more efficient than china [3].

Five major factors lead to differences in the stock market between China and America: 1) market legal environment: China rule of law is not perfect, lack of supervision, the legal system, information disclosure, for violations severely punished severely; 2) the structure of investors: the stock market is dominated by retail investors China chase sell, the U.S. stock market value of the investment is dominated by institutional investors; 3 ) the mainstream media and government departments: China mainstream media "stocks to listen to the party", "the 4000 point is the starting point of bull market", the government's tacit endorsement of intervention in the market, the investors must be self financing, own responsibility, investor education market; 4) knowledge and attitude on the market: Chinese government departments sometimes put the stock market as a The intention of the policy tools, and in the United States, the market will be fully respected, make its own rules play a role; 5) self regulating mechanism of market supply and demand: the United States to implement the registration system, improve the entry and exit mechanism can automatically adjust the stock of supply and demand, Chinese is the essence of the examination and approval system, the lack of effective supply and demand balance adjustment mechanism.

\subsection{Comparison of Secondary Securities Market System}

The differences of stock market trading system between China and America mainly include information disclosure and dividend payment in securities trading.

Chinese listed companies have some problems, such as inaccurate, inadequate, lagging and passive information disclosure. The Ministry of supervision has a lack of efforts to deal with illegal activities in the continuous disclosure of information, and the market lacks incentives to promote timely disclosure of information by enterprises. Investors can not understand the real situation of the investors through the information provided by the listed companies and Will not be able to make the correct value judgment. the United States government focuses on monitoring the information disclosure of listed companies through legislative means, emphasizing the impartiality, transparency and authority of the law. The court will decide that securities violators pay huge punitive damages to shareholders, which is a fatal blow to both the reputation and the economy of the listed company.

The main methods of dividend payment include cash dividend, stock dividend and stock repurchase. The dividend payout ratio of American listed companies is generally higher, and most of the company's profits will be paid directly or indirectly to shareholders. Therefore, the dividend payout policy of American listed companies is relatively stable. The dividend payments of Listed Companies 
in China are mostly stock dividends, and the forms of delivery, delivery, transfer and so on are derived from them. The dividend payout ratio of Listed Companies in China is still at a low level, and most of the net profits of enterprises remained in the enterprise.

\subsection{Comparison of Stock Market Supervision System}

The supervision mechanism of stock market is the guarantee of orderly and efficient operation of stock market, and the supervision system has a direct influence on the development of stock market. The United States tends to effectively supervise the market through legislative means, and the relevant laws will be improved with the development of the economy. The United States adopts a centralized regulatory system, and its regulatory system can be divided into four levels: the federal government, the state government and the self regulatory organizations and non-profit organizations. At present, China has established a more effective stock market supervision system, including four parts: laws, administrative regulations, departmental rules and self-discipline rules.

Insider trading on the US market is strictly prohibited. Although there are criminal penalties for insider trading in China, the implementation is far from enough. Compared with the securities and Exchange Commission of the United States, China's Securities Regulatory Commission has a strong executive body colour, and the State Council has positioned it as a ministerial level public institution. Therefore, China Securities Regulatory Commission will be directly intervened by the government, so it is difficult to independently and objectively exercise the functions of market supervision.

\subsection{Comparison of Stock Market Investor Structure}

At present, the absolute number of China's stock market is still an individual investor, institutional investors in all investors accounted for only $10 \%$. Weak institutional investors are difficult to play an important role in stabilizing the market. The main investors in US stock market are institutional investors, and the stock selection standards of institutional investors are strict and scientific. Institutional investors prefer high dividend, low price earnings, and huge growth potential value stocks, so the stock price in the U.S. stock market can basically reflect its true value.

\section{The Theoretical Basis of the Linkage between Chinese and American Stock Markets}

\subsection{Behavioral Finance}

Behavioral finance theory holds that investors are the main actors in the market, and the behavior of investors can determine the direction and result of the market. The theory analyzes the transmission mechanism of stock market linkage from the point of view of investor behavior. so it can also determine the linkage between the stock markets. Specifically, the factors that affect investor behavior 
include investor categories, range preferences, and information dissemination [4].

\subsection{Hypothesis of Economic Base and Market Contagion}

The hypothesis of economic base is based on the traditional financial theory. The premise of the theory is that the investors in the market are rational. The linkage of stock markets in different countries is based on macroeconomic linkages among countries. If the two economies share common ground, or the economic development is closely related, then the stock market linkage between the two countries can be carried out through macroeconomic linkages. In addition, even if the economy between the two countries are not closely linked, as investors asset allocation in the world, when a country's domestic economy fluctuates, investors will change the investment strategy and asset allocation, thereby affecting the stock market in other countries. In the sub-prime mortgage crisis, the American economic bubble burst, which led to the depression of domestic economy and the decrease of domestic demand. Because China's exports are largely dependent on the United States, China's exports are seriously affected, and the recession in export enterprises has led to volatility in the domestic stock market. Moreover, the rising unemployment rate caused by the depression of export enterprises may further affect China's domestic demand and lead to adverse effects on China's domestic economy.

\section{Research on the Interrelated Ways of Chinese and American Stock Markets}

Because the international stock market correlation is based on the integration of the stock market and economic integration, the trend of the integration of the stock market and the integration of the economy provides a way for the International Stock Market Association.

\subsection{Trade between Countries}

The stock market is a barometer of the national economy, On the one hand, it shows that macroeconomic determines the stock market. On the other hand, it shows that the trend of the stock market is the leading indicator of the macro economy and can reflect the changes of the economic cycle in advance. The changes of macroeconomic development and related factors will appear on the stock market and the overall trend of securities markets in various countries is interrelated and interactive. The trend of the securities market in developed countries, especially as the locomotive of the world economy. The Dow Jones index of the New York stock market and the NASDAQ index have become an important indicator of the expected trend of the securities market in various countries.

\subsection{Economic Spillover Effect}

Spillover effects are the effects of the behavior of an economic entity on the wel- 
fare of another, which is not reflected in money or market transactions. Economic integration makes the "spillover effect" of the volatility of the securities market, that is, the volatility of the market price, is transmitted among different securities markets. The article points out that "spillover effect" means that when a country's capital market fluctuates substantially, it will spread to other markets through the change of investors' behavior in other capital markets.

\subsection{Transnational Listing Has Gradually Increased}

With the integration and internationalization of the stock market, Domestic enterprises can allocate resources around the world, such as issuing corporate bonds or using stock to make direct financing. Since each international stock exchange has its own investor base, it will rapidly expand the shareholder base, increase the liquidity of the stock and enhance the financing capability. Company stock listing in different markets is conducive to improving the company's reputation in the listed market, enhance customer confidence, and promote product marketing. Many famous multinational enterprises, such as "Mercedes Benz" and "HSBC", are listed on different exchanges in the world at the same time. The famous DaimlerChrysler group has been listed on 21 exchanges worldwide. Domestic, such as "Sinopec", "China Unicom" and other enterprises have adopted the "multi listing" approach [5].

\subsection{Stock Companies Operate Globally}

The competition in investment banking is also increasingly globalized for more effective participation in international competition. Big investment banks such as Goldman Sachs, Merrill Lynch, Morgan and Stanley have expanded overseas through acquisitions, mergers, or the establishment of branches. This trend has provided a practical basis for the trend of simultaneous movements in the international stock markets.

\section{An analysis of the Formation Mechanism of Stock Market Interaction in China and the United States}

There are four main transmission channels in China and the United States: international trade channels, financial capital channels, policy channels, and expected channels.

\subsection{International Trade Channels}

The channel of international trade is one of the basic channels, which is explained by the influence of one country's economic expansion on another country. When a country's economy expands, demand for goods increases, and domestic production capacity does not meet demand. This will increase the output of the enterprises in the exporting countries and the employment population, and then expand their domestic demand, leading to the expansion of the economies of the exporting countries. Moreover, according to purchasing power par- 
ity theory, the rise in commodity prices in one country tends to increase the price of the same commodity in another country, leading to an increase in wages, capacity and output. After the sub-prime mortgage crisis in 2007, the European Union replaced the United States as China's largest exporter of trade. However, after the outbreak of the European debt crisis, China's exports to the European Union dropped sharply, resulting in the domestic export enterprises recession. The sub-prime mortgage crisis and the European debt crisis have proved to us as a developing country that relies on exports for economic growth that the economic fluctuations between China and the United States or the European Union are largely determined by trade channels.

\subsection{Financial Capital Channel}

In order to avoid risks and increase profits, investors will make portfolios all over the world. International capital is divided into long-term and short-term capital according to the time limit. Long term capital flows are mainly due to the adjustment of international investors' portfolios in a country when the economic development of a country changes. Such as changes in the proportion of investment in a country's capital, and thus affect the country's financial market development of the supply and demand of funds, affecting the development of the stock market. Short term capital is characterized by liquidity, with arbitrage as its primary objective. When a country's economy changes greatly, there will be arbitrage opportunities compared with another country, and a large number of short-term hot money will enter the country's market for arbitrage. When the scale of hot money is large, it will lead to the volatility of the stock market, and may even lead to serious financial risks.

\subsection{Policy Channel}

Firstly, the policy of a country will affect domestic economic development and trade between the two countries, And then affect the economic ties and stock market linkage. Secondly, because of the deepening of economic globalization, the policies of the two countries tend to be similar in policy, especially in trade, finance and other fields. The response of the two countries in the face of the same shock is also similar.

\subsection{Expected Channel}

The expected channel is based on behavior theory, and behavioral finance assumes that investors in the market are not completely rational. When the stock market fluctuates in foreign countries, the investors expect the operation of some domestic companies and the ability to resist risks, which will lead to similar changes with the domestic market, and thus change their investment strategies, resulting in fluctuations in the domestic stock market. The interaction between the stock market originates from the expected change of investors, and the stronger the ability of investors to obtain information, the higher the efficiency 
of the stock market, and the stronger the linkage will be. In China, there are many domestic investors and relatively few institutional investors. Compared with institutional households, retail investors have limited ability to obtain effective information, and it is easy to follow a series of irrational behaviors such as following the trend. In 2007 subprime mortgage crisis, for example, the United States several major banks and financial institutions lost or even closed down, leading to a significant decline in U.S. stocks. Some domestic institutions and a large number of retail investors have been selling bank shares in large amounts because of psychological panic, leading to a fall in the domestic stock market.

\section{Conclusion and Perspective}

In general, with the perfect and open Chinese economic development and stock market system, China and the United States stock market linkage is gradually increased. Especially in the subprime crisis, China and the United States stock market linkage significantly enhanced. Finally, we make a few suggestions: 1) Strengthen supervision of hot money. The state should strengthen supervision over international hot money. For long-term investment, we should strengthen the import and build the real economy. For short-term speculation Funds, we should improve the early-warning mechanism and improve the macro-economic control system. 2) Accelerate the economic transformation, and adjust the industrial structure. During the financial crisis, many foreign trade enterprises decline in performance, leading to domestic economic fluctuations. There should be reduced to Dependence on foreign trade.

Here are some suggestions. Investors should pay close attention to the linkage between the stock markets of China and the United States. For a long time, the A share market has been less closed and less impacted by international capital. However, with the trend of internationalization becoming more and more obvious, the possibility of the shock of external financial turmoil on China's capital market will increase as the process of economic globalization advances. The inflow of international stock capital into emerging stock markets and the consequent market relations have reduced the cost of funds for emerging markets, improved liquidity and market space depth, and improved market efficiency. However, due to the emerging stock market generally smaller, less liquidity, so easily in the correlation effect under the spillover effects in industrialized countries and emerging stock market turmoil. The fluctuation of the stock market is generally large, massive capital inflows may exacerbate the volatility of the degree of associated amplification.

\section{References}

[1] Dai, M.F., Hou, J., Gao, J.Y., Su, W.Y., Xi, L.F. and Ye, D.D. (2016) Mixed Multifractal Analysis of China and US Stock Index Series. Chaos, Solitons and Fractals. The Interdisciplinary Journal of Nonlinear Science, and Nonequilibrium and Complex Phenomena, 268-275.

[2] Yang, C.P. and Zhou, L.Y. (2016) Individual Stock Crowded Trades, Individual 
Stock Investor Sentiment and Excess Returns. North American Journal of Economics and Finance, 38, 39-53. https://doi.org/10.1016/j.najef.2016.06.001

[3] Huang, Y.-J. and Bacon, F.W. (2009) Can the US Stock Market be Shanghaied?: Evidence of the Impact of China's Emerging Stock Market. Management Research News, 325.

[4] Anonymous (2009) Stock Profiler. US: Stock Profiler. US Profiles W2 Energy Inc., China Coal Energy Co., Ltd., Novo Energies Corporation, \& The Tirex Corporation. M2 Presswire, 125-127.

[5] Gavin, M. (1989) The Stock Market and Exchange Rate Dynamics. Journal of International Money and Finance, 8, 181-200.

https://doi.org/10.1016/0261-5606(89)90022-3 